\title{
DEVELOPING AN INDEX OF THE MALAYSIAN TOURISM AND HOSPITALITY GRADUATES COMPETENCIES
}

\author{
Nurhazani Mohd Shariff \\ Universiti Utara Malaysia \\ Azlan Zainol Abidin \\ Universiti Utara Malaysia
}

\begin{abstract}
The current study develops an index of tourism and hospitality graduates competencies specifically for the case of Malaysian graduates. The process involved four major stages begins with the process of generating the competencies from the literature search, follows by the process of verifying the competencies, then testing for reliability and finally developing the index. The process of generating the competencies ended up with 73 competencies while the competencies verification which involved 30 experts in the tourism and hospitality industry indicated 40 competencies to be further tested. The process of testing for reliability involved a pilot study of 116 respondents and the findings indicated all competencies have high alpha value above 0.5 and were included to be tested for factor analysis in the index development stage. The index of Malaysian tourism and hospitality graduates' competencies consists of eight domains namely Management and Technology Competencies, Leadership Competencies, Organizational Competencies, Personal Effectiveness Competencies, Business-Oriented Competencies, Self-Oriented Competencies, Customer Related Competencies and Innovative Competencies. The index has gone through a systematic process in developing such a tool and significantly contributes to the identification and selection of quality graduates to serve within the tourism and hospitality environment.
\end{abstract}

Keywords: Index; Competency; Tourism; Hospitality; Graduate; Malaysia.

\section{INTRODUCTION}

Today, the tourism and hospitality education in Malaysia is tremendously developed to produce quality graduates to fulfill the industry needs (Zahari, Hanafiah, Othman, Jamaluddin \& Zulkifli, 2010). With the increasing demand for tourism and hospitality graduates, several educational institutions in the country have established the program by giving vital attention to the competencies required by the industry for instance Universiti Teknologi MARA, Universiti Utara Malaysia, Universiti Malaya, Universiti Malaysia Sabah, Universiti Sains

Corresponding author: School of Tourism, Hospitality \& Environmental Management, College of Law, Government \& International Studies, Universiti Utara Malaysia 06010 Sintok, Kedah, Malaysia. Tel: 6012-556 9004; Email: hazani@uum.edu.my 
Malaysia, Taylor's University College, Begi University College, Damansara Utama College and Limkokwing University of Creative Technology. In addition, two hotel sectors are also offering full time and short courses for the tourism and hospitality namely Berjaya University College and Legend International College.

It is agreeable that the tourism and hospitality education programs must have specialized courses which provide students with specific interest area in the industry complying with the Accreditation Commission for Programs in Hospitality Administration (ACPHA) 1992. Many studies stress on the significance of competencies for the tourism and hospitality graduates in order for them to perform in the industry (Goodman \& Sprague, 1991; Jayawardena, 2001; Barrows \& Walsh, 2002; Littlejohn \& Watson, 2004; Zopiatis, 2010). The tourism and hospitality education should consists of five broad abilities and skills which cover the area of marketing orientation, service delivery systems, human resources, physical assets, and management structures and policies (Barrows \& Hobson, 1993). In addition, human resource skills is found to be a vital skill for graduate which compass of coaching, training, negotiating, disciplining, and handling difficult people (William \& Hunter, 1991).

Furthermore, human relation is considered as the most significant skill within the top rated grouping which involves areas such as guest care, employee relations, professionalism and communication (Baum, 2006). Communication skills for instance are viewed as very important criteria for the hiring process of the tourism and hospitality graduates (Geissler \& Martin, 1998). A recent study by Hairi, Ahmad Toee and Razzaly (2011) indicates that the local Malaysian universities are still lacking relevant soft skills competencies which lead to their unemployment in a highly competitive job market. Additionally, the National Economic Action Council also found that there is a mismatch of competency between the industry requirements and the graduates produced by the universities. In 1993, the Ministry of Culture, Arts and Tourism (MOCAT) Malaysia has embarked on the development of National Occupational Skill Standard (NOSS) which comprising of 33 job areas in the hotel industry, 30 job areas in the tourism and travel sector, eight job areas in the theme park sector and six job areas in the recreational scuba diving. The purpose of NOSS for the tourism and hospitality industry is to assist training institutions in preparing competent persons to meet actual job requirements. Hence it must be noted that the designing of the program is only to make vocational and skill training in Malaysia more relevant to industry's needs regardless of the customers and general public overall improvement in the quality of services. With so many institutions in Malaysia offering the program, the quality of the curriculum structure has become major issue in the tourism and hospitality education. Therefore, the competencies required by the industry need to be compiled into the curriculum as to produce quality graduates. Thus, a study was conducted to develop a standard index to measure the competencies of tourism and hospitality graduates as requested by the industry.

\section{OVERVIEW OF THE LITERATURE}

A competency or abilities and skills model is defined as an integrating education and training, aligning both with the needs of the labor market and promoting mobility for individuals (Van der Klink \& Boon, 2002; Delamare Le Deist \& Winterton, 2005). Various models of competencies 
are being developed for the purpose of producing qualified graduates. A Competencies Value Framework (CVF) developed by Quinn, Thompson, Faerman and McGrath (2003) offers an opportunity to examine key managerial skills and competencies based on organizational theory. It is also considered versatile to be applied to all industry sectors as it takes a more general approach to management competencies and skills necessary for managers to be effective. In addition, the values and principles of the CVF are also applied by other researchers and are accepted as a standard model in the Australian context (Dimmock, 1999; Colyer, 2000; Walo, 2000; Breen, Walo \& Dimmock, 2004).

Moreover, an Australian Quality Framework was developed for a purpose to standardize qualifications across Australia and to present graduates with certificates that open the door to employment (Australian Chamber of Commerce and Industry, 2002). The framework covers comprehensive tasks associated with different jobs in the industry which includes detailed sets of procedural steps for undertaking tasks in various functions for instance housekeeping and bar work. Margerison (2001) proposed a team competency model with performance being assessed on nine competencies. This is based on the fact that with global competition and technological advances, organizational success is depending more on team efforts rather than individual. It is important to note that a competency model describes the qualities required of a worker to be successful in a position, on a team to achieve or exceed the strategic goals of the organization (Delamare, Le Deist \&Winterton, 2005; Teodorescu, 2006).

Additionally, the Employment and Training Administration (ETA) developed by the Australian Chamber of Commerce and Industry, and the Business Council of Australia, (2002) focuses on skills acquisition and assessment to the competency model process for determining the needs of business and employers and the requirements of skilled workers. The ETA consists of nine generic skill groups similar to the "employability skills" framework proposed in a study by Australian industry representative groups. In the tourism and hospitality perspective, Sandwith (1993) developed a model consists of several items such as empowering employees and building an effective team under the leadership domain. The administrative domain includes competencies such as accounting and finance and personnel management. On the other hands, the interpersonal domain includes competencies such as writing effectively, speaking clearly and listening.

Further, Kearns (2001) offered a model for clustering the generic skills which include the cognitive cluster; interpersonal skills cluster; enterprise, innovation and creativity cluster; and work readiness and work habits cluster. The cognitive cluster consists of items such as learning, thinking, analytical capability and problem solving. The interpersonal skills cluster consists of communication, customer service and cultural understanding. The enterprise, innovation and creativity cluster consists of several items for instance enterprise, entrepreneurship, creativity and innovation. Finally, the work readiness and work habits cluster involves items such as basic skills, using technology, business orientation, planning and organizing and self-management. Previously, Bach and Milman (1996) demonstrated four clusters of skills required by the hospitality industry. The clusters consist of (1) Business functional areas for instance marketing, accounting and finance; (2) Hospitality \& Tourism functional areas namely accommodations, food service, travel, transportation and travel agency; (3) Personal 
skills which refer to individual characteristics or traits of an effective manager and finally (4) Analytical skills which cover the ability to master various types of information through computer literacy, research, report and many more.

\section{METHODOLOGY AND ANALYSIS OF RESULTS}

Based on the previous studies by Churchill (1979) and DeVellis (1991), the developed index derived with four major stages namely the process of generating the competencies, the process of verifying the competencies, testing for reliability and developing the index competencies.

\subsection{Generating the Competencies}

The first step in developing the index involved the generation of graduates competencies. Based on the previous literature, 73 competencies were compiled such as interpersonal skill, ability to use technology, communication skill, customer service skill, critical thinking skill, decision making skill, selling skill and strategic planning. All these 73 competencies were further tested for content validity and clarity using 30 experts from various sectors of tourism and hospitality. The findings from the experts indicated 33 competencies did not represent tourism and hospitality graduate's competencies thus they were eliminated from the list namely developing subordinates, collective performance, adaptability, selling, system thinking skill, presentation skill, training, decision making skill, analysis skill, current knowledge, understanding theory, continuous training, time management, negotiation skill, SWOT analysis, listening skill, stress management, research skill, enterprise skill, building trust, policy, and accountability. This also included cultural understanding and cultural diversity. As for management performance, organization performance, hotel organization performance, financial accounting skill, financial management skill, adaptability, adapt to change, legal aspect and ethical, these were the competencies classified as 'similar, redundant and confusing items' by the experts. Table 1 depicts the 33 competencies eliminated from the first stage.

Table 1: Graduates Competencies Eliminated from Items Generation Stage

\begin{tabular}{cc}
\hline No. & Competencies \\
\hline 1 & Developing subordinates \\
2 & Collective performance \\
3 & Management performance \\
4 & Adaptability \\
5 & Selling \\
6 & System thinking skill \\
7 & Presentation skill \\
8 & Organization performance \\
9 & Cultural diversity \\
10 & Training \\
11 & Decision making skill \\
12 & Analysis skill \\
\hline
\end{tabular}


Table 1: Graduates Competencies Eliminated from Items Generation Stage (cont)

\begin{tabular}{lc}
\hline No. & Competencies \\
\hline 13 & Financial accounting skill \\
14 & Business orientation \\
15 & Legal aspects \\
16 & Current knowledge \\
17 & Understanding theory \\
18 & Ethical \\
19 & Continuous learning \\
20 & Time management \\
21 & Negotiation skill \\
22 & SWOT analysis \\
23 & Listening skill \\
24 & Stress management skill \\
25 & Cultural understanding \\
26 & Hotel organization performance \\
27 & Research skill \\
28 & Enterprise skills \\
29 & Financial management skill \\
30 & Building trust \\
31 & Policy \\
32 & Adapt to change \\
33 & Accountability \\
\hline
\end{tabular}

\subsection{Verifying the Competencies}

30 experts were used as respondents in this stage and were asked to rate the importance of competencies to be possessed by the graduates. The findings revealed that 40 items were consistent to be presented as tourism and hospitality graduates' competencies (Table 2). 86.7\% respondents indicated communication skill, mathematical skill and business fundamental skill as the most important competencies which the graduates need to have before entering the industry. The findings then followed by $83.3 \%$ respondents agreed that another three competencies namely interpersonal skill, planning and organizing skill and motivation as mostly important competencies for the graduates. In addition, $80.0 \%$ respondents indicated problem solving skill and recording skill as another two highly important competencies which the graduates need to possess while working within the industry.

Further, the findings indicated $76.7 \%$ respondents agreed that the items ability to work as teamwork, customer service skill, professionalism skill, coordinating skill, marketing skill and ability to control resources as important competencies which should be possessed by the tourism and hospitality graduates. The findings also revealed that three items were agreed by the respondents as competencies which must be provided by the educational institutions. 
$73.3 \%$ of them identified mentoring skill, preparing budget and ability to use tools as among the important competencies. Furthermore, $70.0 \%$ of the respondents also reached a consistent result by indicating ability to inform information and staffing as two competencies for the tourism and hospitality graduates to possess in the industry.

The findings also indicated that technology awareness and reading skill as important competencies which the tourism and hospitality graduates must have (66.7\%). Additionally, $63.3 \%$ of the respondents found that writing skill as moderate important competency for the graduates. Followed by $60 \%$ of the respondents agreed that critical thinking skill, ability to monitor staff, computer application skill, networking and ability to support staff are moderately important to be possessed by the graduates. Meanwhile, $56.7 \%$ respondents named the ability to use technology and conflict resolution skill as the least important competencies. Integrity skill and ability to clarify company's objectives also presented as the least important competencies which graduates must have to work in the industry $(53.3 \%)$.

Table 2: Graduates Competencies Derived From Items Verification Stage

\begin{tabular}{ccc}
\hline No. & Competencies & \% of Importance \\
\hline 1 & Communication skill & 86.7 \\
2 & Mathematical skill & 86.7 \\
3 & Business fundamental skill & 86.7 \\
4 & Interpersonal skill & 83.3 \\
5 & Planning \& organizing skill & 83.3 \\
6 & Motivation & 83.3 \\
7 & Problem solving skill & 80.0 \\
8 & Recording skill & 80.0 \\
9 & Ability to work as teamwork & 76.7 \\
10 & Customer service skill & 76.7 \\
11 & Professionalism skill & 76.7 \\
12 & Coordinating skill & 76.7 \\
13 & Marketing skill & 76.7 \\
14 & Ability to control resources & 76.7 \\
15 & Mentoring skill & 73.3 \\
16 & Preparing budget & 73.3 \\
17 & Ability to use tools & 73.3 \\
18 & Ability to inform information & 70.0 \\
19 & Staffing & 70.0 \\
20 & Technology awareness & 66.7 \\
21 & Reading skill & 66.7 \\
22 & Writing skill & 63.3 \\
23 & Critical thinking skill & 60.0 \\
24 & Monitoring staff & 60.0 \\
25 & Computer application skill & 60.0 \\
\hline
\end{tabular}


Table 2: Graduates Competencies Derived From Items Verification Stage (cont)

\begin{tabular}{lcc}
\hline No. & Competencies & \% of Importance \\
\hline 26 & Networking & 60.0 \\
27 & Ability to support staff & 60.0 \\
28 & Ability to use technology & 56.7 \\
29 & Conflict resolution skill & 56.7 \\
30 & Integrity & 53.3 \\
31 & Ability to clarify company's objectives & 53.3 \\
32 & Reliability & 50.0 \\
33 & Entrepreneurship skill & 50.0 \\
34 & Flexibility & 50.0 \\
35 & Ability to delegate & 50.0 \\
36 & Initiative & 43.3 \\
37 & Learning skill & 40.0 \\
38 & Vision & 36.7 \\
39 & Creative skill & 36.7 \\
40 & Strategic planning & 36.7 \\
\hline
\end{tabular}

\subsection{Testing for Reliability}

Once the competencies were verified through the process of items verification, they were analyzed for reliability to estimate the degree to which a measurement is free of error. This analysis was performed using Cronbach's coefficient alpha with a purpose to reflect how well the items in the tool are positively correlated to one another. Additionally, the procedure involved calculating the average inter-correlations among the items measuring the concept. A high internal consistency is indicated by alpha value of 1 and above. In this stage, a pilot study was conducted using 116 tourism and hospitality graduates and the findings indicated that all 40 competencies revealed high Cronbach's coefficient alpha value above 0.5 ranged from .830 to .784 .

\subsection{Developing the Index Competencies}

Based on the reliability test in the third stage, all the 40 competencies were further tested for the final stage of competencies index development. This stage involved factor analysis to determine the number of domains or factors derived. The findings in this stage indicated 11 domains with eigenvalues above one. Additionally, all the 40 competencies had factor loading above 0.4 . However, three domains only consisted of one competency which consequently could not be tested for reliability thus they were eliminated from the index. The competencies were identified as marketing skill, planning and organizing skill networking. The remaining eight domains were named as Domain One: Management and Technology Competencies, Domain Two: Leadership Competencies, Domain Three: Organizational Competencies, Domain Four: Personal Effectiveness Competencies, Domain Five: Business-Oriented 
Competencies, Domain Six: Self-Oriented Competencies, Domain Seven: Customer Related Competencies and Domain Eight: Innovative Competencies.

Domain One: Management And Technology Competencies consisted of ten competencies with eigenvalues of 12.078 , a variance of $30.194 \%$ and alpha value of .833 . Ability to use technology derived with the highest factor loading of .789 whilst business fundamental skill derived with the lowest factor loading of .429. Meanwhile, Domain Two: Leadership Competencies consisted of six items with eigenvalues of 3.592, a variance of $8.981 \%$ and alpha value of .879. Motivation derived with the highest factor loading of .797 whilst strategic planning indicated the lowest factor loading of .574. Further, Domain Three: Organizational Competencies consisted of seven competencies with eigenvalues of 2.787 , a variance of $6.969 \%$ and alpha value of .881 . This domain consisted of ability to delegate with the highest factor loading of .776 whilst vision with the lowest factor loading of .420. In addition, Domain Four: Personal Effectiveness Competencies derived with four competencies with eigenvalues of 2.029 , a variance of $5.072 \%$ and alpha value of .761 . This domain consisted of initiative with the highest factor loading of .786 whilst critical thinking with the lowest factor loading of .467 .

Further, Domain Five: Business-Oriented Competencies derived with three competencies with eigenvalues of 1.819 , a variance of $4.547 \%$, and alpha value of .688. This domain consisted of professionalism skill with the highest factor loading of .815 and integrity skill with the lowest factor loading of .527. Domain Six: Self-Oriented Competencies derived with eigenvalues of 1.705 , a variance of $4.261 \%$ and alpha value of .804. This domain also consisted of three competencies namely writing skill, reading skill and mathematical skill. The highest factor loading was indicated by writing skill with .863 whilst the lowest factor loading was indicated by mathematical skill with .724. Additionally, Domain Seven: Customer Related Competencies consisted of two competencies namely customer service skill and problem solving skill. This domain indicated eigenvalues of 1.385 and a variance of $3.463 \%$ with alpha value of .505 . Domain Eight: Innovative Competencies also consisted of two competencies namely ability to work as teamwork and communication skill. This domain indicated eigenvalues of 1.296 and a variance of $3.241 \%$ with alpha value of .568. The developed index is depicted in Table 3 .

Table 3: Index Competencies of Tourism and Hospitality Graduates

\begin{tabular}{ll}
\hline Domain 1 & Management and Technology Skills \\
Ability to use technology & Ability to use tools \\
Computer application skill & Coordinating skill \\
& Recording skill \\
Creative skill & Technology awareness \\
Entrepreneurship skill & Learning skill \\
Business fundamental skill \\
\hline
\end{tabular}


Table 3: Index Competencies of Tourism and Hospitality Graduates (cont)

\begin{tabular}{|c|c|}
\hline Domain 2 & $\begin{array}{l}\text { Leadership Skills } \\
\text { Motivation } \\
\text { Ability to inform information } \\
\text { Ability to support staff } \\
\text { Mentoring skill } \\
\text { Monitoring staff } \\
\text { Strategic planning }\end{array}$ \\
\hline Domain 3 & $\begin{array}{l}\text { Organizational Skills } \\
\text { Ability to delegate } \\
\text { Ability to clarify company's objectives } \\
\text { Staffing } \\
\text { Ability to control resources } \\
\text { Preparing budget } \\
\text { Conflict resolution skill }\end{array}$ \\
\hline Domain 4 & $\begin{array}{l}\text { Personal Effectiveness Skills } \\
\text { Initiative } \\
\text { Reliability } \\
\text { Flexibility } \\
\text { Critical thinking skill }\end{array}$ \\
\hline Domain 5 & $\begin{array}{l}\text { Business-Oriented Skills } \\
\text { Professionalism skill } \\
\text { Interpersonal skill } \\
\text { Integrity skill }\end{array}$ \\
\hline Domain 6 & $\begin{array}{l}\text { Self-Oriented Skills } \\
\text { Writing skill } \\
\text { Reading skill } \\
\text { Mathematical skill }\end{array}$ \\
\hline Domain 7 & $\begin{array}{l}\text { Customer Related Skills } \\
\text { Customer service skill } \\
\text { Problem solving skill }\end{array}$ \\
\hline Domain 8 & $\begin{array}{l}\text { Innovative Skills } \\
\text { Ability to work as teamwork } \\
\text { Communication Skill }\end{array}$ \\
\hline
\end{tabular}

\section{DISCUSSION}

Generally, the procedure of developing the index involved several stages. The first stage started by generating the items of graduate's competencies from literature search. This included the process of searching and identifying the core tourism and hospitality graduate's competencies. Based from the literature, it was found that several models of graduates' competencies were 
already developed. Few of them focused on tourism and hospitality whilst others researched generally on the basis of competencies needed from the graduates. Eventually, the process of searching for graduate's competencies ended up with 73 items including from the available models such as CVF (Quinn et. al., 2003), Australian Quality Framework (Australian Chamber of Commerce and Industry, 2002), Competency Framework (Margerison, 2001), ETA Australian Chamber of Commerce and Industry \& Business Council of Australia, 2002 (Ennis, 2008), and Generic Skills Framework (Kearns, 2001). In addition, it also considered the two specific models in tourism and hospitality introduced by Sandwith (1993) and Four Clusters of Skills (Bach \& Milman, 1996). All the competencies were grouped and those which redundant were eliminated from the list.

The final stage of developing the index involved factor analysis to identify the domains and competencies represent the domains. The analysis derived with 11 domains but only eight domains of competencies for tourism and hospitality graduates were confirmed since the other three domains comprised of only one competency. These three domains were eliminated from the index. The first domain namely Management and Technology Skills consists of 10 competencies. Six of them are categorized into management competencies namely, coordinating skill, recording skill, creative skill, entrepreneurship skill, learning skill and business fundamental skill. The competencies derived are significantly consistent to ETA (Ennis, 2008) which focuses on nine tier including management competencies. Moreover, the competencies are also supported in CVF Model (Quinn et. al., 2003) and also in a study conducted by Barrows and Hobson (1993) which suggested management competencies as important skills for managers to be effective. Another four competencies are labeled into technology skills namely, ability to use technology, ability to use tools, computer application skill and technology awareness. Additionally these skills are similar to the model developed by Margerison (2001) which suggested the important role of technology in organizational success. In fact, these skills are agreeable with the ETA (Ennis, 2008) which comprises of two technical competencies namely the industry-wide technical competencies and the industry-specific technical competencies. Thus, this domain significantly presents the most important graduate's competencies as perceived by the tourism and hospitality industry particularly in Malaysia.

The second domain derived is named as Leadership Skills. The domain consists of six competencies which are significantly related to leadership except for strategic planning. These main five leadership items are represented by motivation, ability to inform information, ability to support staff, mentoring skill and monitoring staff. As derived in Sandwith's Model (1993), the leadership skills are vital and eventually contributed as a major domain in the model. Similarly, the findings conclude that the tourism and hospitality graduates eventually need to have strong leadership abilities and skills so that they are able to lead others and willing to be led by others in order to perform better task for achieving organization's vision. The third domain comprises of seven competencies which the tourism and hospitality graduates must have before and specifically while they are working in the industry. The domain named Organizational Skills significantly present five vital management skills in the tourism and hospitality industry which are consistent to CVF Model (Quinn et. al., 2003). The skills such as, ability to clarify company's objectives, staffing, ability to control resources, preparing budget and vision are seen similar as what comprised in the internal process model of CVF. Eventually, these competencies need to be possessed by the graduates in order to organize the organization's management 
process particularly in dealing with the employees. Another two competencies namely, ability to delegate and conflict resolution skill however are seen more toward leadership skills even though they did not fall into the second domain. These competencies can also be seen in CVF Model under the category of human relations model. Moreover, these competencies are also consistent to the study by Barrows and Hobson (1993).

Personal Effectiveness Skills is named for the fourth domain and is referred as competencies represent the tourism and hospitality graduate individually. As a person with tourism and hospitality backgrounds, the domain reflects a personal characteristic of specific graduate. The domain comprises of four major personal effectiveness competencies namely, initiative, reliability, flexibility and critical thinking skill. Since these skills are similar to competencies in tier one of ETA (Ennis, 2008), the domain is also named accordingly to the domain one of ETA. Furthermore, these skills are categorized under the cognitive cluster of Generic Skills Framework (Kearns, 2001). Additionally, the competencies are used to be labeled as interpersonal skills in some competencies model for instance the Four Cluster of Skills developed by Bach and Milman (1996) and Sandwith's Model (Sandwith, 1993). In addition, the skills are also consistent to the study undertaken by Hersey and Blanchard (1988). The fifth domain in IGAS which is known as Business-Oriented Skills composes of three competencies related to individual businessoriented skills. The domain comprises of professionalism skill, interpersonal skill and integrity skill. This is similar to the competencies suggested in Sandwith's Model (Sandwith, 1993). Interpersonal skill is also emphasized by Alderson (1993) as a vital skill to increase cultural awareness among employers and customers in an organization. As for both professionalism and integrity skills, these skills are probably important to be possessed by the graduates since they are dealing with various backgrounds of customers internationally. The industry eventually believes that the tourism and hospitality graduates must build up these skills within themselves in order to survive in the future challenges.

The next domain is presented by the Self-Oriented Skills. The sixth domain consists of three additional competencies required from the tourism and hospitality graduates. The competencies are writing skill, reading skill and mathematical skill. It can be seen that these competencies may not be perceived as the most important competencies by the tourism and hospitality graduates but the competencies are considered important by the industry, thus they need to be considered by the academic institutions when preparing the curriculum structure. These are similar as those competencies comprised in the ETA (Ennis, 2008) and suggested by Barrows and Hobson (1993). Customer Related Skills is named for the seventh domain which consists of two major competencies which the tourism and hospitality graduates must have before and after entering the industry. The competencies are identified as customer service skill and problem solving skill. Eventually, these competencies are consistent to what was noted in studies by Ladki (1993) and Tesone and Ricci (2005) which indicated that customer needs is vital to be acknowledge by the graduates in order for them to work in the industry. However, these competencies were inconsistent to what was noted in studies by Wilks and Hemsworth (2011) and Yang, Partlow, Anand and Shukla (2014) which focused more on the leadership competencies of the graduates in order for them to work in the industry. Additionally, the final domain which is named Innovative Skills consists of two competencies which are the ability to work as teamwork and communication skill. These competencies are significant to many studies regarding tourism and hospitality competencies such as Umbriet (1993), Sneed and Heiman (1995) and Breiter and 
Clements (1996). It is suggested that communication skill plays important role in determining the graduates' survival in the industry since they are directly involved with the customers.

\section{CONCLUSION}

The issue of having graduates which can fulfill the industry needs is mostly concerned the competencies possess by the graduates. Similarly, the issue is becoming a vital aspect in the tourism and hospitality industry. This study concerned on the competencies which should be possessed by the tourism and hospitality graduates as required by the industry. This is important for the graduates to survive in the future challenges within the industry itself. Additionally, the index has been developed more for the purpose of determining competencies for tourism and hospitality graduates in the case of Malaysian higher educational institutions. The study also provides a significant index of graduates' competencies for the tourism and hospitality education programs, thus to produce qualified graduates according to the industry needs. It can be summarized that the index has gone through a systematic methodology approach and well established process of developing a standard index which can be applied in other related studies concerning the identification of graduates' competencies.

The index also consists of competencies required by the industry, thus these competencies are vital in order for the graduates to enter the industry and furthermore to survive with the future challenges. By having a standard measurement to determine competencies needed from the graduates, the industry can promise effective and qualified employees to deal with customers' needs. This aspect significantly contributes to fulfill the gaps exist between what the educational institutions provide and the industry expectations. Specifically, it also contributes to the needs of stakeholders' involvement in designing and improving the tourism and hospitality education curriculum so as to create a well-balanced approach of theory and practical. Industry plays important role in determining the competencies of the graduates thus the development of a standard index significantly contributes to the identification and selection of quality graduates to serve within the hospitality environment.

\section{ACKNOWLEDGEMENT}

The study is financially sponsored under the Fundamental Research Grant Scheme.

\section{REFERENCES}

Alderson, S. (1993). Reframing management competence: focusing on the top management team. Personnel Review, 22(6), 53-62.

Australian Chamber of Commerce and Industry, and the Business Council of Australia (2002). Employability skills for the future. Canberra: Department of Education, Science and Training.

Bach, S. A., \& Milman, A. (1996). A novel technique for reviewing a hospitality management curriculum. Hospitality and Tourism Educator, 8(1), 37-40.

Barrows, C. W., \& Hobson, J. S. P. (1993). A model for teaching service management for hospitality. International Journal of Contemporary Hospitality Management, 5(3), 32-36. 
Barrows, C. W., \& Walsh, J. (2002). Bridging the gap between hospitality management programmes and the private club industry. International Journal of Contemporary Hospitality Management, 14(3), 120-127.

Baum, T. (2006). Reflections on the nature of skills in the experience economy: challenging traditional skills models in hospitality. Journal of Hospitality and Tourism Management, 13(2), 124-135.

Breen, H., Walo, M., \& Dimmock, K. (2004). Assessment of tourism and hospitality management competencies: a student perspective (presentation). In K. A. Smithe \& C. Schott (Eds), Proceedings of Tourism Research: Advances and Applications, New Zealand Tourism and Hospitality Research Conference, Wellington, NZ, 8-10 December, Tourism Management Group, Victoria Management School, Victoria University of Wellington, Wellington, NZ.

Breiter, D., \& Clements, C. J. (1996). Hospitality management curricula for the 21 st century. Hospitality and Tourism Educator, 8(1), 61-4.

Churchill, G. A. (1979). A paradigm for developing better measure of marketing constructs. Journal of Marketing Research, 16(1), 64-73.

Colyer, S. (2000). Organizational culture in selected Western Australian sport organizations. Journal of Sport Management, 14(4), 321-34.1

Delamare Le Deist, F., \&Winterton, J. (2005). What is competence? Human Resource Development International, 8(1), 27-46.

DeVellis, R. F. (1991). Scale development: theory and applications. Newbury Park, CA: Sage.

Dimmock, K. (1999). Management style and competitive strategies among tourism firms in the northern rivers. Tourism Management, 20(3), 323-339.

Ennis, M. R. (2008). Competency Models: A Review of the Employment and Training Administration (ETA). USA: Department of Labor.

Geissler, J., \& Martin, L. (1998). Are we staying current in the preparation of our hospitality management graduates? Journal of Hospitality and Tourism Education, 10(3), 47-50.

Goodman, R., \& Sprague, L. (1991). The future of hospitality education: meeting the industry's needs. The Cornell Hotel and Restaurant Administration Quarterly, 32(2), 66-70.

Hairi, F., Ahmad Toee, M. N. \& Razzaly, W. (2011). Employers'perceptions on soft skills of graduates: A study of Intel elite soft skill training. A Paper Presented at the International Conference on Teaching \& Learning in Higher Education (ICTLHE 2011).

Hersey, P., \& Blanchard, K. H. (1988). Management of organizational behavior. Englewood Clift, NJ: Prentice Hall.

Jayawardena, C. (2001). Challenges in international hospitality management education. International Journal of Contemporary Hospitality Management, 13(6), 310-15. 
Kearns, P. (2001). Generic skills for the new economy. a review of research relating to generic skills. Adelaide, Australia: National Centre for Vocational Education Research.

Ladki, S. M. (1993). Hospitality education: the identity struggle. International Journal of Hospitality Management, 12(3), 243-251.

Littlejohn, D., \& Watson, S. (2004). Developing graduate managers for hospitality and tourism. International Journal of Contemporary Hospitality Management, 16(7), 408-14.

Margerison, C. (2001). Team competencies. Team Performance Management, 7(7/8), 117-122.

Quinn, R., Faerman, S., Thompson, M., \& McGrath, M. (2003). Becoming a master manager: a competency framework (3rd edition). USA: John Wiley and Sons.

Sandwith, P. (1993). A hierarchy of management training requirements: the competency domain model. Public Personnel Management, 22(1), 43-63.

Sneed, J., \& Heiman, R. (1995). What program and student characteristics do recruiters consider most important? Hospitality and Tourism Educator, 7(4), 47-49.

Teodorescu, T. (2006). Competence versus competency: what is the difference? Performance Improvement, 45(10), 27-31.

Tesone, D., \& Ricci, P. (2005). Job competency expectations for hospitality and tourism employees: perceptions of educational preparation. Journal of Human Resources in Hospitality and Tourism, 4(2), 53-64.

Umbriet, T. (1993). Essential skills: what graduates need to succeed. Hosteur, 10-12.

Van der Klink, M., \& Boon, J. (2002). The investigation of competencies within professional domains. Human Resource Development International, 5(4), 411-424.

Walo, M. (2000). The contribution of internship in developing industry-relevant management competencies in tourism and hospitality graduates. Unpublished Master of Business Thesis, Southern Cross University, Lismore, NSW, Australia.

Wilks, D., \& Hemsworth, K. (2011). Soft skills as key competencies in hospitality higher education: matching demand and supply. Tourism and Management Studies, 7, 131-139.

William, P. W., \& Hunter, M. (1991). Recruitment and retention insights for the hotel industry. F.I.U. Hospitality Review, 9(1), 51-58.

Yang, L-T., Partlow, C. G., Anand, J., \& Shukla, V. (2014). Assessing the competencies needed by hospitality management graduates in India. Journal of Hospitality \& Tourism Education, 26(4), 153-165.

Zahari, M. S., Hanafiah, M. H., Othman, Z., Jamaluddin, M. R. \& Zulkifly, M. I. (2010). Declining interest of hospitality students toward careers in hotel industry: who's to be blamed? Interdisciplinary Journal of Contemporary Research in Business, 2(7), 269-287.

Zopiatis, A. (2010). Is it art or science? Chef's competencies for success. International Journal of Hospitality Management, 29(3), 459-467. 